\title{
Genetic evolution of Marek's disease virus in vaccinated poultry farms
}

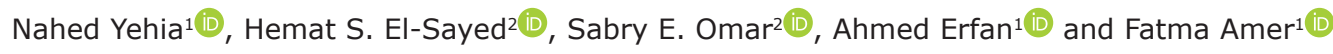 \\ 1. Reference Laboratory for Veterinary Quality Control on Poultry Production, Animal Health Research Institute, \\ Agricultural Research Center, Dokki, Giza 12618, Egypt; 2. Department of Poultry Diseases, Benha Provincial Laboratory, \\ Animal Health Research Institute, Agricultural Research Center, Giza, Egypt. \\ Corresponding author: Nahed Yehia, e-mail: nahedyehia@gmail.com \\ Co-authors: HSE: hemat.elsayed@yahoo.com, SEO: sabryomar2014@gmail.com, AE: ahmed.erfan10000@gmail.com, \\ FA: fatmaamer29@gmail.com
}

Received: 30-12-2020, Accepted: 09-04-2021, Published online: 28-05-2021

doi: www.doi.org/10.14202/vetworld.2021.1342-1353 How to cite this article: Yehia N, El-Sayed HS, Omar SE, Erfan A, Amer F (2021) Genetic evolution of Marek's disease virus in vaccinated poultry farms, Veterinary World, 14(5): $1342-1353$.

\begin{abstract}
Background and Aim: The Marek's disease virus (MDV) is a neoplastic disease causing serious economic losses in poultry production. This study aimed to investigate MDV occurrence in poultry flocks in the Lower Egypt during the 2020 breakout and genetically characterized $M e q, g L$, and ICP4 genes in field strains of MDV.

Materials and Methods: Forty samples were collected from different breeds from eight Egyptian governorates in 2020. All flocks had received a bivalent vaccine (herpesvirus of turkey FC-126 + Rispens CVI988). However, weight loss, emaciation, reduced egg production, paralysis, and rough/raised feather follicles occurred. Samples were collected from feather follicles, liver, spleen, and nerve tissue for diagnosis by polymerase chain reaction. MDV genetic characterization was then performed by sequencing the $M e q, g L$, and ICP4 genes of five positive samples representing different governorates and breeds.

Results: A total of 28 samples were positive for MDV field strains, while two were related to MDV vaccinal strains. All samples tested negative for ALV (A, B, C, D, and J) and REV. Phylogenetic analysis of the Meq gene of sequenced samples revealed that all MDVs were related to the highly virulent European viruses (Gallid herpesvirus 2 ATE and PC12/30) with high amino acid (A.A.) identity 99.2-100\%. Alternatively, there was low A.A. identity with the vaccine strains CVI988 and 3004 (up to $82.5 \%$ ). These results indicate that further investigation of the efficacy of current Egyptian vaccines is required. The Egyptian strains also harbor a specific mutation, allowing clustering into two subgroups (A and B). By mutation analysis of the $\mathrm{Meq}$ gene, the Egyptian viruses in our study had R101K, P217A, and E263D mutations present in all Egyptian viruses. Furthermore, R176A and T180A mutations specific to our strains contributed to the high virulence of highly virulent strains. There were no mutations of the $g L$ or ICP4 genes.
\end{abstract}

Conclusion: Further studies should evaluate the protection contributed by current vaccines used in Egypt.

Keywords: genetic characterization, $g L, I C P 4$, marek's disease virus, Meq.

\section{Introduction}

Marek's disease virus (MDV) is a highly oncogenic, lymphoproliferative, and neuropathic disease. It is an economically devastating infectious disease for the poultry industry due to emaciation, lower egg production, and carcass condemnations $[1,2]$. It is also commonly identified in domestic chickens and more rarely in turkey and quail species [3]. The disease manifests in chickens 3-4 weeks of age or older and is usually diagnosed at 12 and 30 weeks of age [4]. The infection is airborne and horizontally transmitted to other chickens. Although vertical transmission to offspring occurs, it is rare [5]. MDV was widespread globally, and as a disease threat, continues to be an important area of research [6]. A major concern is the

Copyright: Yehia, et al. Open Access. This article is distributed under the terms of the Creative Commons Attribution 4.0 International License (http://creativecommons.org/licenses/by/4.0/), which permits unrestricted use, distribution, and reproduction in any medium, provided you give appropriate credit to the original author(s) and the source, provide a link to the Creative Commons license, and indicate if changes were made. The Creative Commons Public Domain Dedication waiver (http://creativecommons.org/ publicdomain/zero/1.0/) applies to the data made available in this article, unless otherwise stated. continued evolution of the virus and the emergence of more virulent MDV pathotypes despite an extensive vaccination regime in the poultry industry [7]. There are three MDV serotypes (MDV-1, 2, and 3), which have major differences between their genomes and biological features [8,9]. MDV-1 includes all virulent oncogenic strains and their attenuated forms used as a vaccine. MDV-2 includes the naturally avirulent, nonpathogenic, and non-oncogenic strain isolated in chickens, some of which are used as vaccines. MDV-3 includes the herpesvirus of turkeys (HVTs) [10]. Only MDV-1 strains cause disease in chickens. The MDV-1 strains are the most commonly used for vaccination, whereas avirulent MDV-2 and MDV-3 strains have also been exploited for vaccine development. MDV-2 strains have been employed, particularly for bivalent vaccines, together with HVT [4]. Alternatively, there are four MDV-1 pathotypes, including mild (m), virulent (v), very virulent (vv), and very virulent plus $\left(\mathrm{vv}^{+}\right)$strains [11]. Many MDV sequences have also been described in various countries [12-14].

MDV replicates in $\mathrm{B}$ and $\mathrm{T}$ lymphocytes cause lymphoma of the peripheral nervous system, visceral 
organs, and skin $[15,16]$. Despite the intensive CVI988 vaccination policy [10], MDV infection will still spread in poultry. This prediction is due to acquired mutations contributing to increased virulence [17-19], mishandling or incorrect storage of the vaccine, or the presence of immunosuppressive diseases [20].

The MDV genome is a double-stranded DNA structure of about $175 \mathrm{~kb}$, consisting of long (U.L.) and short (U.S.) unique regions, each flanked by inverted repeats (TRL, IRL, IRS, and TRS) [21]. All MDV serotypes have the same general structure, but serotype I contains unique genes found in the repeated regions of the genome, including the $\mathrm{Meq}$ oncogene and $p p 38, V I L 8$, and vTR [22]. The Meq gene is expressed abundantly in MDV-infected cells and MDV tumor cells and plays an important role in the transformation process [23]. The Meq gene has also been studied as a potential causal factor for the high oncogenicity of the virus $[13,14,24]$. Losses or deletion of the $M e q$ gene leads to loss of oncogenicity as recorded in MD-2 and MD-3 strains [21,25], although other genes also serve important roles in lymphoma development [20].

MDV contains ten glycoproteins ( $g L, g M, g H$, $g B, g C, g N, g K, g D, g I$, and $g E$ ), and is encoded by UL1, UL10, UL22, UL27, UL44, 49.5 UL53, US6, and $U S 7$, respectively [13]. While the $\mathrm{gH}$ and $g L$ proteins form a hetero-oligomeric complex [26], which plays a significant role in the viral entry of the host cell, $g L$ and $g C$ exhibit an important role in the development of a cytotoxic immune response [12]. Recent evidence associates a four-amino acid (A.A.) deletion within the putative signal cleavage site of $g L$ with increased virus virulence [13]. Numerous studies conducted in Egypt have also investigated the epidemiology of the MDV strains circulating in Egypt about outbreaks in poultry flocks $[27,28]$. However, minimal data regarding the molecular evolution of MDV strains circulating in Egypt are available.

This study aimed to investigate the current situation of tumor viruses in eight governorates in Lower Egypt during 2020. The study also investigates the genetic evolution of $M e q, g L$, and ICP4 genes in field viruses of MDV recently detected from infected vaccinated flocks.

\section{Materials and Methods}

Ethical approval

This study does not require the approval of the Institute Animal Ethics Committee

\section{Study period and location}

We collected forty samples from January 2020 to December 2020. The samples were processed in Reference Laboratory for Veterinary Quality Control on Poultry Production, Animal Health Research Institute. -

\section{Sampling}

Forty samples from eight governorates were collected from the Lower Egypt and from different breeds (layer and breeder farms). Twenty to thirty birds from each flock were checked. Samples of the 3-4 feather follicles and liver, spleen, and nerves showing gross pathologic lesions indicative of MDV were taken from individual birds. The samples from each farm were pooled and tested as a single sample. All flocks had received the bivalent vaccine (HVT FC-126 + Rispens CVI988). The tissue was also homogenized using Qiagen tissue lyser, suspended in sterile PBS, and centrifuged at $3000 \mathrm{rpm}$ at $4^{\circ} \mathrm{C}$ for $15 \mathrm{~min}$ to get the supernatants. The specimens were stored at $-20^{\circ} \mathrm{C}$ until use. DNA extraction was performed, after which gross pathological lesions were confirmed on necropsy.

\section{DNA extraction for PCR}

The total nucleic acid extraction was performed using the QIAamp mini elutes virus spin kit (Qiagen, Germany, $\mathrm{GmbH}$ ). In brief, $200 \mu \mathrm{L}$ of the tissue homogenate supernatant was incubated at $56^{\circ} \mathrm{C}$ for 15 min using a $25 \mu \mathrm{L}$ Qiagen protease and $200 \mu \mathrm{L}$ A.L. lysis buffer. The remaining steps were completed according to the manufacturer's instructions.

\section{Amplification of MDV, ALV (A, B, C, D, and J), and REV DNA}

Tumor viruses were detected using the Phusion ${ }^{\circledR}$ high fidelity DNA polymerase (Thermo, MA, USA) and specific primers for MDV and other tumor viruses \{ALV (A, B, C, D, and J) and REV\} [29-34]. Furthermore, the differentiation between field and vaccinal strains of MDV was achieved using (BamH1 132 bp tandem repeat) primers [29] (Supplementary Table-.1) according to the manufacturer's instructions. Specific DNA amplicons were then identified by agarose gel electrophoresis, and a gel documentation system (Alpha Innotech, Biometra, Germany) was used to capture gel photosystem.

DNA sequencing of $M e q, g L$, and ICP4 genes of MDV

Representative positive samples of different origins were selected for the molecular characterization of $M e q, g L$, and ICP 4 genes. The Phusion ${ }^{\circledR}$ high fidelity DNA polymerase (Thermo, MA, USA) and primers specific to each gene [35-37] were used according to the manufacturer's instructions (Supplementary Table-1).

Purification of PCR product was then conducted using the QIAquick Gel Extraction Kit (Qiagen, Hilden, Germany), while sequencing was conducted using the BigDye Terminator v3.1 Cycle Sequencing Kit (Applied Biosystems, California, USA) with gene-specific primers. Nucleotide sequences were also obtained using an ABI 3500 Genetic Analyzer (Life Technologies, California, USA). The sequences in this study were published with specific accession numbers in The National Center for Biotechnology Information.

\section{Genetic and phylogenetic analysis}

DNA and A.A. sequences were aligned with 20 related strains from Europe, China, the USA, 
and Egypt GenBank using the MegAlign module of the DNASTAR software (Lasergene; version 7.2; DNASTAR, Madison, WI, USA). The phylogenetic tree was built using MEGA (version 7; www. megasoftware.net) with moderate strength, and 1000 bootstrap replicates using a maximum likelihood tree method. The pair-wise nucleotide percent identity was also performed using DNASTAR software.

\section{Results}

\section{Clinical signs}

The observed clinical signs in all affected flocks were loss of weight, emaciation, and reduced egg production in layers. Twenty of the affected flocks had neural lesions (development of paralysis of the legs, wings, and neck). The other ten affected flocks had neural lesions and visceral tumors, while ten other flocks showed visceral tumors only, with $60 \%$ of affected birds displaying rough and raised feather follicles.

\section{Gross pathology}

All affected birds showed loss of striations and thickening of their nerve trunk. Twenty of the affected flocks showed gray-white foci neoplastic tissues in the visceral organs, including the liver, kidney, spleen, gonads, heart, lungs, and skeletal muscles.

\section{Polymerase chain reaction}

Based on the 434-bp positive amplification of the Bam1H-H132 bp tandem repeats, 30 samples were identified as positive for MDV from different breeds (28 field strain and two vaccinal strains). All other tested samples were negative for $\operatorname{ALV}$ (A, B, $\mathrm{C}$, and D) and REV (Table-1).

\section{Molecular characterization of Meq gene in Egyptian} viruses

Phylogenetic analysis indicated that the five samples from field samples identified in this study were genetically related to the virulent European and Chinese viruses (Y.A., ATE, PC12/130, and GX070060) with a 99.2-99.4\% homology. The viruses in this study also shared a 99.4-99.8\% homology and with other Egyptian viruses. They also shared a homology of $82.5 \%$ with the vaccinal strains; CV1988 and 3004 (Figure-1). All viruses in this study had short $M e q$ sequences than the mild and vaccinal strains, with 177-bp length. A.A. mutations were also detected in the Meq_Egypt strains compared with the Gallid herpesvirus 2 ATE strain at R101K, and P217A as Egyptian viruses, Chinese viruses (LMS, Y.A., WS03, and GX070060), and USA (TK, X, and N), respectively. The E263D mutation was specific for all Egyptian strains. R176A and T180A were also specific to Egyptian viruses in this study.

The A.A. sequences of the $M e q$ gene were downloaded from GenBank for 20 reference strains. Then, they were aligned with the strains presently studied, revealing that the $\mathrm{Meq}$ gene phylogenetic tree is classified into three groups. Group I contained the Chinese viruses (LMS, Y.A., WS03, and GX070060) and the European viruses (AT-2539 and PC12/130). The Egyptian viruses were also closely related to the vv European viruses and divided into two subgroups (a and b; Figure-2). The MDV viruses of this study were also related to subgroup A due to a specific characteristic nucleotide mutation. Alternatively, Group II was related to the virulent strains and $\mathrm{vv}$ viruses isolated from the USA (TK, X, and N). Group III comprised mildly virulent viruses and vaccinal strains (CV1988, CU-2, 814, and 3004) (Figure-2).

\section{Molecular characterization of the $g L$ gene in Egyptian viruses}

Phylogenetic analysis indicated that $g L$ in the MDV strain studied was genetically similar to that of the vv European and Chinese viruses (LMS, ATE, and PC12/130) with a $99.7 \%$ homology. The A.A identity

\begin{tabular}{|c|c|c|c|c|c|c|c|c|c|c|c|c|c|c|c|c|c|c|c|c|c|}
\hline \multicolumn{22}{|c|}{ Percent Identity } \\
\hline \multirow{20}{*}{ 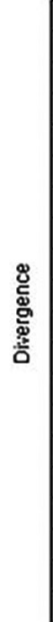 } & & 1 & 2 & 3 & 4 & 5 & 6 & 7 & 8 & \begin{tabular}{|l|}
9 \\
\end{tabular} & 10 & 11 & 12 & 13 & 14 & 15 & 16 & 17 & 18 & & \multirow{3}{*}{$\begin{array}{l}\text { Gallid-herpesvirus-2-YA-China-2010 } \\
\text { Gallid-herpesvirus-2-GX070060-China-2008 }\end{array}$} \\
\hline & 1 & & 100.0 & 99.4 & 99.5 & 99.0 & 99.1 & \begin{tabular}{|l|}
99.4 \\
\end{tabular} & 83.0 & 83.0 & 99.2 & 99.4 & 99.4 & 99.4 & 99.2 & \begin{tabular}{|l|}
99.2 \\
\end{tabular} & \begin{tabular}{|c|}
99.2 \\
\end{tabular} & \begin{tabular}{|l|}
99.2 \\
\end{tabular} & \begin{tabular}{|l|}
99.2 \\
\end{tabular} & 1 & \\
\hline & 2 & 0.0 & & 99.4 & 99.5 & 99.0 & 99.1 & 99.4 & 83.0 & 83.0 & 99.2 & 99.4 & 99.4 & 99.4 & 99.2 & 99.2 & 99.2 & \begin{tabular}{|l|l}
99.2 \\
\end{tabular} & 99.2 & 2 & \\
\hline & 3 & 0.7 & 0.7 & & 99.9 & 98.8 & 98.9 & 99.2 & 83.0 & 83.0 & 99.4 & 99.4 & 99.4 & 99.4 & 99.4 & 99.4 & 99.4 & \begin{tabular}{|l|}
99.4 \\
\end{tabular} & 99.4 & 3 & \multirow{3}{*}{$\begin{array}{l}\text { Gallid-herpesvirus-2-strain-ATE -Hungary-2004 } \\
\text { Gallid-herpesvirus-pC12-130 -USA-2011 } \\
\text { Gallid-herpesvirus-2-L-USA-2004 }\end{array}$} \\
\hline & 4 & 0.6 & 0.6 & 0.1 & & 98.9 & 99.0 & 99.3 & 83.1 & 83.1 & 99.4 & 99.4 & 99.5 & 99.5 & 99.4 & 99.4 & 99.4 & 99.4 & 99.4 & 4 & \\
\hline & 5 & 1.2 & 1.2 & 1.5 & 1.3 & & \begin{tabular}{|l|}
99.9 \\
\end{tabular} & 99.3 & 82.7 & 82.7 & 99.1 & 98.7 & 98.8 & 98.8 & 99.1 & \begin{tabular}{|l|}
99.1 \\
\end{tabular} & 99.1 & \begin{tabular}{|l|}
99.1 \\
\end{tabular} & \begin{tabular}{|l|}
99.1 \\
\end{tabular} & 5 & \\
\hline & 6 & 1.1 & 1.1 & 1.3 & 1.2 & 0.1 & & 99.4 & 82.8 & 82.8 & 99.2 & 98.8 & 98.9 & 98.9 & 99.2 & 99.2 & 99.2 & 99.2 & 99.2 & 6 & Gallid-herpesvirus-2-TK -USA-2004 \\
\hline & 7 & 0.8 & 0.8 & 1.0 & 0.9 & 0.9 & 0.8 & & 83.1 & 83.1 & 98.9 & 98.9 & 99.0 & 99.0 & 98.9 & 98.9 & 98.9 & 98.9 & 98.9 & 7 & \multirow{3}{*}{$\begin{array}{l}\text { Gallid-herpesvirus-2-W -USA-2004 } \\
\text { Gallid-herpesvirus-2-3004-Russia-2007 } \\
\text { Gallid-herpesvirus-2-CV1988 -USA-2007 }\end{array}$} \\
\hline & 8 & 0.8 & 0.8 & 0.8 & 0.7 & 1.1 & 1.0 & 0.7 & & $\mid 100.0$ & 82.5 & 82.5 & 82.6 & 82.6 & 82.5 & 82.5 & 82.5 & 82.5 & 82.5 & 8 & \\
\hline & 9 & 0.8 & 0.8 & 0.8 & 0.7 & 1.1 & 1.0 & 0.7 & 0.0 & & 82.5 & 82.5 & 82.6 & 82.6 & 82.5 & 82.5 & 82.5 & 82.5 & 82.5 & 9 & \\
\hline & 10 & 1.0 & 1.0 & 0.8 & 0.7 & 1.1 & 1.0 & 1.3 & 1.3 & 1.3 & & 99.4 & 99.5 & 99.5 & 99.8 & 99.8 & 99.8 & 99.8 & 99.8 & 10 & \multirow{2}{*}{$\begin{array}{l}\text { Gallid-alphaherpesvirus-2-Fayoum-2018 } \\
\text { Gallid-herpesvirus-2-Egypt1 -2013 }\end{array}$} \\
\hline & 11 & 0.8 & 0.8 & 0.8 & 0.7 & 1.6 & 1.4 & 1.3 & 1.3 & 1.3 & 0.7 & & 99.9 & 99.9 & 99.4 & 99.4 & 99.4 & 99.4 & 99.4 & 11 & \\
\hline & 12 & 0.7 & 0.7 & 0.7 & 0.6 & 1.4 & 1.3 & 1.2 & 1.2 & 1.2 & 0.6 & 0.1 & & 100.0 & 99.5 & \begin{tabular}{|l|}
99.5 \\
\end{tabular} & 99.5 & \begin{tabular}{|l|}
99.5 \\
\end{tabular} & 99.5 & 12 & Gallid-herpesvirus-2Egypt2-2013 \\
\hline & 13 & 0.7 & 0.7 & 0.7 & 0.6 & 1.4 & 1.3 & 1.2 & 1.2 & 1.2 & 0.6 & 0.1 & 0.0 & & 99.5 & 99.5 & 99.5 & 99.5 & 99.5 & 13 & Gallid-herpesvirus-2-Egypt3-2013 \\
\hline & 14 & 1.0 & 1.0 & 0.8 & 0.7 & 1.1 & 1.0 & 1.3 & 1.3 & 1.3 & 0.2 & 0.7 & 0.6 & 0.6 & & 100.0 & 100.0 & 100.0 & 100.0 & 14 & Gallid-herpesvirus-2-LE1 \\
\hline & 15 & 1.0 & 1.0 & 0.8 & 0.7 & 1.1 & 1.0 & 1.3 & 1.3 & 1.3 & 0.2 & 0.7 & 0.6 & 0.6 & 0.0 & & 100.0 & 100.0 & 100.0 & 15 & Gallid-herpesvirus-2-LE2 : \\
\hline & 16 & 1.0 & 1.0 & 0.8 & 0.7 & 1.1 & 1.0 & 1.3 & 1.3 & 1.3 & 0.2 & 0.7 & 0.6 & 0.6 & 0.0 & 0.0 & & 100.0 & 100.0 & 16 & \multirow{4}{*}{$\begin{array}{l}\text { Gallid-herpesvirus-2-LE3 } \\
\text { Gallid-herpesvirus-2-LE4 } \\
\text { Gallid-herpesvirus-2-LE5 }\end{array}$} \\
\hline & 17 & 1.0 & 1.0 & 0.8 & 0.7 & 1.1 & 1.0 & 1.3 & 1.3 & 1.3 & 0.2 & 0.7 & 0.6 & 0.6 & 0.0 & 0.0 & 0.0 & & 100.0 & 17 & \\
\hline & 18 & 1.0 & 1.0 & 0.8 & 0.7 & 1.1 & 1.0 & 1.3 & 1.3 & 1.3 & 0.2 & 0.7 & 0.6 & 0.6 & 0.0 & 0.0 & 0.0 & 0.0 & & 18 & \\
\hline & & 1 & 2 & 3 & 4 & 5 & 6 & 7 & 8 & 9 & 10 & 11 & 12 & 13 & 14 & 15 & 16 & 17 & 18 & & \\
\hline
\end{tabular}

Figure-1: Amino acid (A.A.) identities and divergence of Meq gene of sequenced viruses compared to other selected strains from European, china and American strains. The figure shows comparative alignment of Meq gene showed that Meq A.A. identity percent of $99.2-99.4 \%$ with European and china strains YA, ATE, PC12/130, and 99.4-99.8\% and with other Egyptian and $82.5 \%$ with vaccinal strains CV1988 and 3004. 
Table-1: Epidemiological data of collected samples, clinical signs, and result of PCR.

\begin{tabular}{|c|c|c|c|c|c|c|}
\hline No. & Year & Breed & Production & Governorate & Clinical Signs & Result of PCR BamH1-H \\
\hline 1. & $1 / 2020$ & High line & Layer & Dakahleya & $\begin{array}{l}\text { Loss of weight, emaciation, reduced } \\
\text { egg production, paralysis of the legs }\end{array}$ & Positive MDV (field strain) \\
\hline 2. & $5 / 2020$ & Avian & Breeders & Sharkia & $\begin{array}{l}\text { Loss of weight, emaciation, reduced } \\
\text { egg production, paralysis of the } \\
\text { legs, wings and neck }\end{array}$ & Positive MDV (field strain) \\
\hline 3. & $3 / 2020$ & High line & Layer & Gharbeya & $\begin{array}{l}\text { Loss of weight, emaciation, reduced } \\
\text { egg production, paralysis of the } \\
\text { legs, wings and neck }\end{array}$ & Negative \\
\hline 4. & $2 / 2020$ & High line & Layer & Kaliobeya & $\begin{array}{l}\text { Loss of weight, emaciation, reduced } \\
\text { egg production, paralysis of the } \\
\text { legs, wings and neck, paralysis of } \\
\text { the legs, wings and neck }\end{array}$ & Positive MDV (field strain) \\
\hline 5. & $5 / 2020$ & $H \& N$ & Layer & Kafr elsheikh & $\begin{array}{l}\text { Loss of weight, emaciation, reduced } \\
\text { egg production, paralysis of the } \\
\text { legs, wings and neck }\end{array}$ & Positive MDV (field strain) \\
\hline 6. & $8 / 2020$ & Cobb & Breeder & Gharbeya & $\begin{array}{l}\text { Loss of weight, emaciation, reduced } \\
\text { egg production, paralysis of the } \\
\text { legs, wings and neck }\end{array}$ & Positive MDV (field strain) \\
\hline 7. & $9 / 2020$ & $\mathrm{H} \& \mathrm{~N}$ & Layer & Giza & $\begin{array}{l}\text { Loss of weight, emaciation, reduced } \\
\text { egg production, paralysis of the } \\
\text { legs, wings, and neck }\end{array}$ & Positive MDV (field strain) \\
\hline 8. & $2 / 2020$ & High line & Layer & Giza & $\begin{array}{l}\text { Loss of weight, emaciation, reduced } \\
\text { egg production, paralysis of the } \\
\text { legs, wings, and neck }\end{array}$ & Positive MDV (field strain) \\
\hline 9. & $7 / 2020$ & Cobb & Breeder & Behira & $\begin{array}{l}\text { Loss of weight, emaciation, reduced } \\
\text { egg production paralysis of the legs, } \\
\text { wings and neck }\end{array}$ & Positive MDV (field strain) \\
\hline 10. & $11 / 2020$ & Red ISA & Breeder & Sharkia & $\begin{array}{l}\text { Loss of weight, emaciation, reduced } \\
\text { egg production paralysis of the legs, } \\
\text { wings, and neck }\end{array}$ & Negative \\
\hline 11. & $12 / 2020$ & Dokki 4 & Layer & Sharkia & $\begin{array}{l}\text { Loss of weight, emaciation, reduced } \\
\text { egg production, paralysis of the } \\
\text { legs, wings, and neck }\end{array}$ & Positive MDV(field strain) \\
\hline 12. & $7 / 2020$ & Novogen & Layer & Behira & $\begin{array}{l}\text { Loss of weight, emaciation, reduced } \\
\text { egg production, paralysis of the } \\
\text { legs, wings, and neck }\end{array}$ & Positive MDV (field strain) \\
\hline 13. & $8 / 2020$ & Avian & Layer & Kaliobeya & $\begin{array}{l}\text { Loss of weight, emaciation, reduced } \\
\text { egg production, rough and raised } \\
\text { feather follicles, paralysis of the } \\
\text { legs, wings and neck }\end{array}$ & Negative \\
\hline 14. & $10 / 2020$ & Hubbard & Broiler & Behira & $\begin{array}{l}\text { Loss of weight, emaciation, } \\
\text { reduced egg production, rough and } \\
\text { raised feather follicles }\end{array}$ & Positive MDV (field strain) \\
\hline 15. & $1 / 2020$ & Baladi & Layer & Sharkia & $\begin{array}{l}\text { Loss of weight, emaciation, reduced } \\
\text { egg production, rough and raised } \\
\text { feather follicles, paralysis of the } \\
\text { legs, wings, and neck }\end{array}$ & Positive MDV (vaccinal strain) \\
\hline 16. & $5 / 2020$ & High line & Layer & Dakahleya & $\begin{array}{l}\text { Loss of weight, emaciation, reduced } \\
\text { egg production, rough and raised } \\
\text { feather follicles, paralysis of the } \\
\text { legs, wings, and neck }\end{array}$ & Negative \\
\hline 17. & $9 / 2020$ & Hubbard & Broiler & Kaliobeya & $\begin{array}{l}\text { Loss of weight, emaciation, reduced } \\
\text { egg production, rough and raised } \\
\text { feather follicles, paralysis of the } \\
\text { legs, wings, and neck }\end{array}$ & Negative \\
\hline 18. & $11 / 2020$ & Red ISA & Breeder & Behira & $\begin{array}{l}\text { Loss of weight, emaciation, reduced } \\
\text { egg production, paralysis of the } \\
\text { legs, wings, and neck }\end{array}$ & Positive MDV (field strain) \\
\hline 19. & $8 / 2020$ & High line & Layer & Dakahleya & $\begin{array}{l}\text { Loss of weight, emaciation, reduced } \\
\text { egg production, paralysis of the } \\
\text { legs, wings, and neck }\end{array}$ & Positive MDV (field strain) \\
\hline 20. & $4 / 2020$ & $H \& N$ & Layer & Giza & $\begin{array}{l}\text { Loss of weight, emaciation, reduced } \\
\text { egg production, paralysis of the } \\
\text { legs, wings, and neck }\end{array}$ & Positive MDV (field strain) \\
\hline 21. & $6 / 2020$ & Avian & Broiler & Giza & $\begin{array}{l}\text { Loss of weight, emaciation, reduced } \\
\text { egg production, paralysis of the } \\
\text { legs, wings, and neck }\end{array}$ & Positive MDV (field strain) \\
\hline 22. & $4 / 2020$ & High line & Layer & Behira & $\begin{array}{l}\text { Loss of weight, emaciation, reduced } \\
\text { egg production paralysis of the legs, } \\
\text { wings, and neck }\end{array}$ & Positive MDV (field strain) \\
\hline
\end{tabular}


Table-1: (Continued).

\begin{tabular}{cclll}
\hline No. & Year & Breed & Production Governor \\
\hline 23. & $9 / 2020$ & Cobb & Broiler & Dakahleya \\
24. $12 / 2020$ & Baladi & Layer & Kaliobeya \\
& & & \\
25. $3 / 2020$ & High line Layer & Behira \\
26. $7 / 2020$ & H\&N & Layer & Kaliobeya \\
27. $2 / 2020$ & Cobb & Breeder & Sharquia \\
28. & $6 / 2020$ & Cobb & Breeder & Kaliobeya \\
29. & $12 / 2020$ & Avian & Breeder & Giza
\end{tabular}

30. 11/2020 High line Layer Behira

Loss of weight, emaciation, reduced Positive MDV (field strain) egg production, rough and raised feather follicles, paralysis of the legs, wings, and neck

Loss of weight, emaciation, reduced Positive MDV (field strain) egg production, rough and raised feather follicles

Loss of weight, emaciation, reduced Positive MDV (field strain) egg production, rough and raised feather follicles

Loss of weight, emaciation, reduced Negative egg production

Loss of weight, emaciation , Positive MDV (field strain) reduced egg production

Loss of weight, emaciation, reduced Positive MDV (field strain) egg production, rough and raised feather follicles, paralysis of the legs, wings and neck Loss of weight, emaciation, reduced Negative egg production, raised feather follicles, paralysis of the legs, wings and neck

31. 4/2020 Cobb Broiler Sharquia

Loss of weight, emaciation and reduced egg production, rough, raised feather follicles, paralysis of the legs, wings, and neck

\section{2. $12 / 2020 \mathrm{H} \& \mathrm{~N}$ Layer Behira \\ 33. $7 / 2020$ Avian Breeder Giza}

34. 9/2020 High line Layer

35. 6/2020 Baladi Layer Gharbeya

36. $3 / 2020$ Cobb Breeder Behira

37. 8/2020 Cobb Breeder Giza

38. 10/2020 High line Layer

Kafr elsheikh Loss of weight, emaciation, reduced Positive MDV (field strain) egg production, rough and raised feather follicles, paralysis of the

legs, wings, and neck

39. 8/2020 H\&N Layer Sharquia Loss of weight, emaciation, reduce
egg production, rough, raised
feather follicles, paralysis of the legs, wings and neck Emaciation, reduced egg Negative production, rough, raised feather follicles, paralysis of the legs, wings and neck

The table shows governorates, breeds, type of production, and year of collected samples and clinical signs observed and result of PCR. MDV=Marek disease virus

percentage also reached $96.9-99.7 \%$ with the TK and $\mathrm{N}$ strains, and $99.7 \%$ with the other Egyptian viruses, mildly virulent viruses, and the vaccinal strains; CV1988 and CU-2 (Figure-3). No mutation was detected in comparison to the Gallid herpesvirus-2 strain ATE from China.
The phylogenetic tree of the $g L$ gene also shows it clustered into two major groups (Figure-4). The MDV studied here was related to Group I, consisting of Egyptian and Chinese viruses and vv European viruses. Alternatively, Group 2 comprised vv + viruses from the USA (TK, X, and N). 


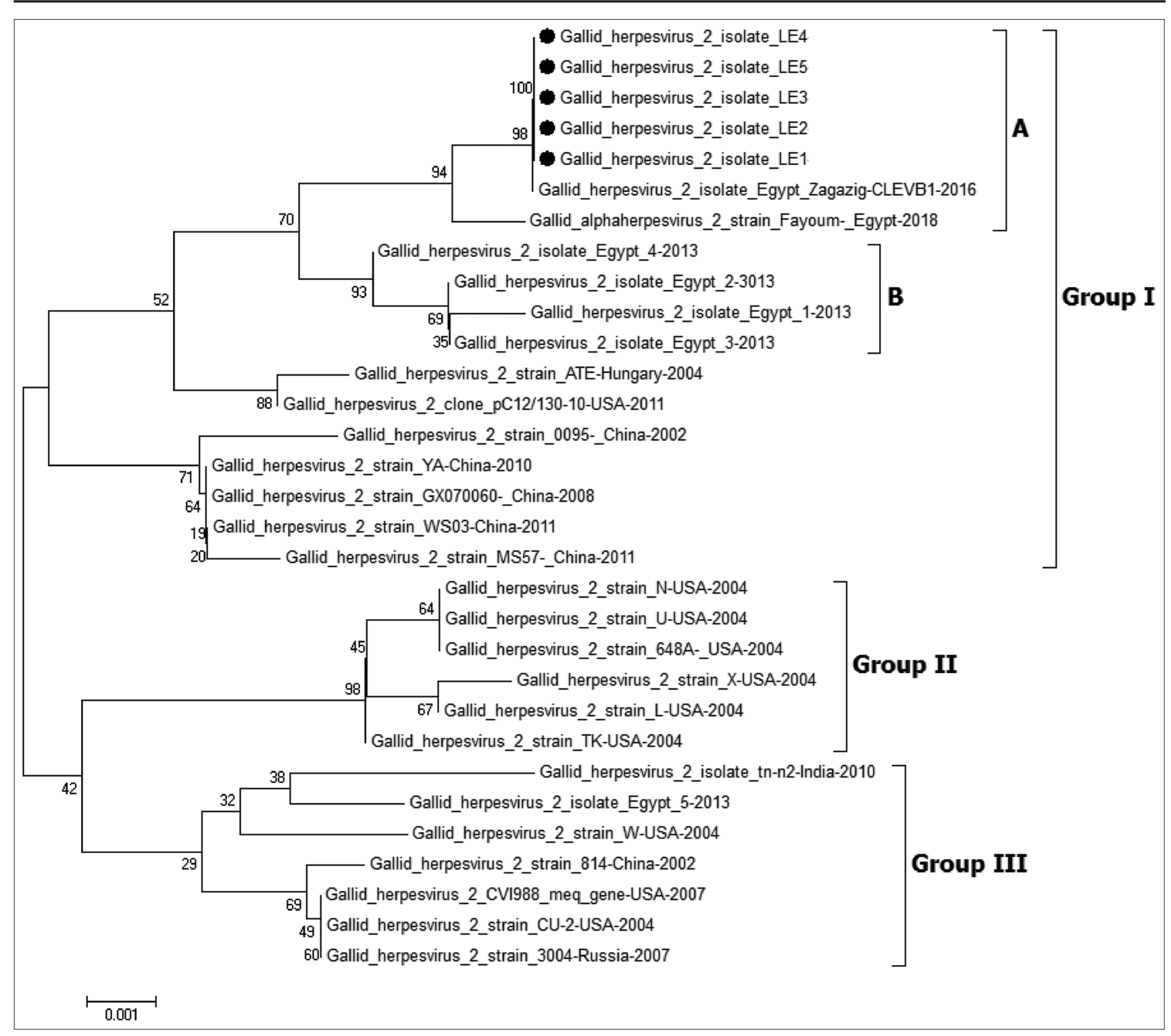

Figure-2: Phylogenetic tree of Meq gene of Marek disease virus (MDV). The figure shows The phylogenetic analysis of Meq gene of MDV gene reveling that all Egyptian strains cluster were related to very virulent European strains (ATE, PC12/130) and cluster into two subgroups ( $\mathrm{A}$ and $\mathrm{B}$ ). The MDV viruses in our study are indicated with a black dot.

Molecular characterization of the ICP4 gene in Egyptian viruses

From the perspective of the ICP4 phylogeny, the Egyptian viruses studied were genetically related to prototype vv European and Chinese viruses (Y.A., ATE, PC12/130, and GX070060), respectively, with $100 \%$ homology, and to the vv USA viruses (RB1B and MD70), with a $98.9 \%$ homology and to mildly virulent and vaccinal strains; (CU2 and CV198), with $100 \%$ homology (Figure-5). No mutation was detected compared to the Gallid herpesvirus-2 strain ATE from China.

For phylogenetic analysis, the ICP4 was classified into three groups. The Egyptian viruses of this study were related to those classified into Group I, including the Chinese viruses (LMS, Y.A., WS03, and GX070060) and the vv European viruses (AT-2539 and PC12/130). Group II comprised the virulent and vV viruses isolated from the USA, whereas Group III contained the mildly virulent viruses; CV1988 and CU-2 (Figure-6).

\section{GenBank accession numbers}

Sequences generated in this study were submitted to GenBank. Meq: MT748026- MT748030. ICP4: MT748031-MT748035 and $g l$ : MT748036-MT748040 (Table-2).

\section{Discussion}

Marek's disease, caused by the MDV, is a highly infectious neoplastic chicken disease that is preventable with vaccination. Although Egyptian hatcheries adopt an intense policy of MDV vaccination using CV1988 or CV1988+HVT at 1-day of age, several cases of vaccine failure have been reported recently $[32,38,39]$. The appearance of new virulent MDV viruses accounts for the MDV vaccine failure [3]. Transcriptional activity of MDV in tumor cells is also limited to repeat regions, including viral telomerase 


\begin{tabular}{|c|c|c|c|c|c|c|c|c|c|c|c|c|c|c|c|c|c|c|c|c|}
\hline \multicolumn{10}{|c|}{} \\
\hline
\end{tabular}

Figure-3: Amino acid (A.A.) identities and divergence of $g L$ gene of sequenced viruses compared to other selected strains from European, China, and American strains. The figure shows comparative alignment of Meq gene showed that $g L$ A.A. identity percent of $99.7 \%$ with European and china strains YA, ATE, PC12/130 and 99.7\% A.A. identity with other Egyptian strains, mildly virulent strain, and vaccinal strain.

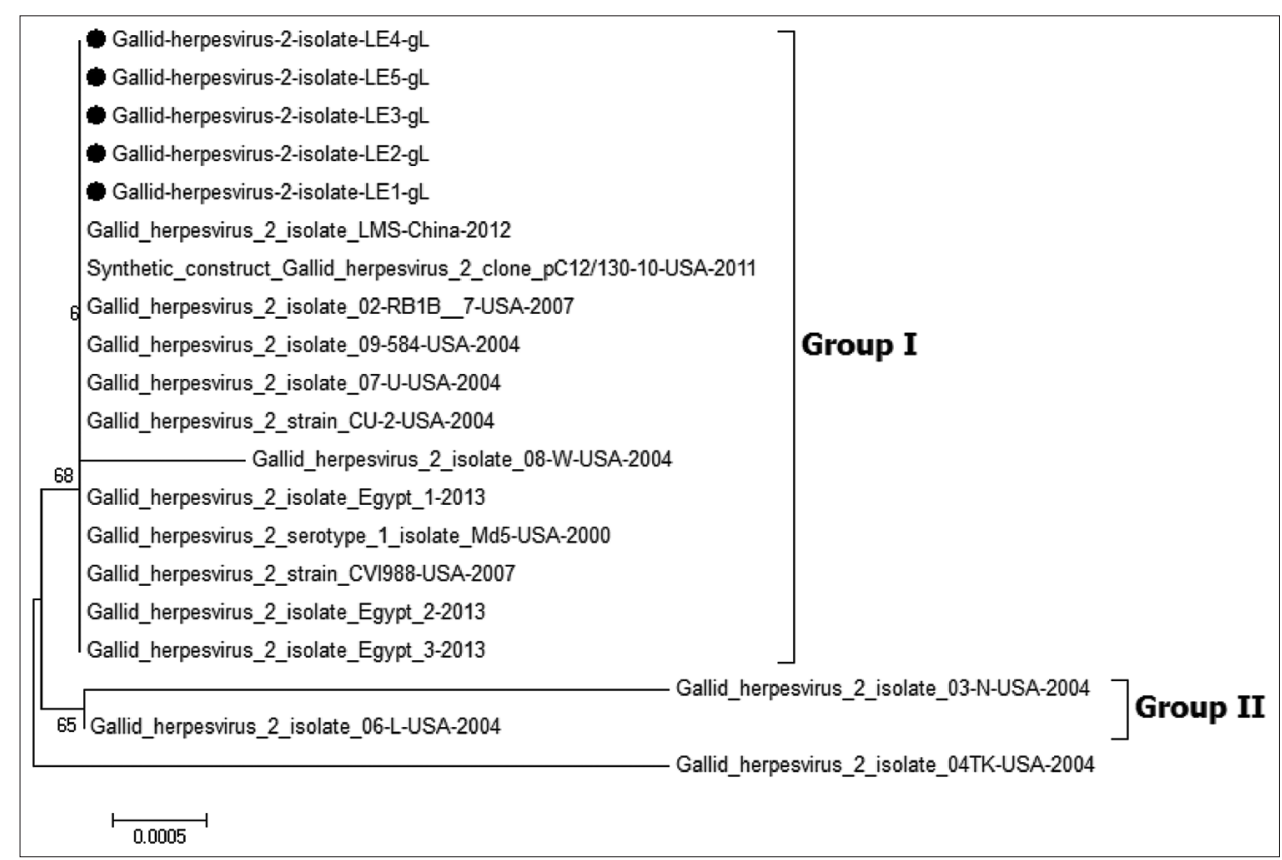

Figure-4: Phylogenetic tree of $g L$ gene of Marek disease virus (MDV). The figure shows the phylogenetic analysis of $g L$ gene of MDV gene reveling that all Egyptian strains cluster were related to very virulent European strains (ATE, PC12/130). The MDV viruses in our study are indicated with a black dot.

RNA, viral $I L-8, M e q, p p 38$, and ICP4 [40-42]. The $M e q, I L-8$, and ICP4 genes are reportedly associated with virulence [42] that evolved more rapidly than other DNA viruses [18]. Nevertheless, literature regarding the molecular composition and evolution of MDV viruses that circulate in Egypt is limited. In this study, we identified circulating MDV in eight governorates from Egypt and studied the molecular evolution of the field strains of MDV by sequencing the $M e q, I C P 4$, and $g L$ genes.

In this study, 40 samples were collected from different provinces in Egypt. Marek's disease virus appeared in 30 samples by PCR, five of which were sequenced for $M e q, g L$, and $I C P 4$ genes. The molecular analysis of Meq, $g L$, and ICP4 genes in 5 MDVs was related to the vv European strains, ATE, and PC12/130, with high homology (99.2-99.4\%, 99.7\%, and $100 \%$, respectively), as previously described by Mitra et al. [29], Hassanin et al. [37], Zanaty et al. [43]. The Meq gene was then used to determine the virulence of MDV strains by the point mutations detected. Studies have shown that these mutations can increase the virus's increased virulence and oncogenicity [20]. Transactivation of Meq can also result in cell transformation $[44,45]$. Phylogenetic analysis of Meq classified MDV into three groups (vv European 


\begin{tabular}{|c|c|c|c|c|c|c|c|c|c|c|c|c|c|c|c|c|c|c|c|}
\hline \multicolumn{10}{|c|}{ Percent Identity } \\
\hline
\end{tabular}

Figure-5: Amino acid (A.A.) identities and divergence of ICP4 gene of sequenced viruses compared to other selected strains from European, China, and American strains. The figure shows comparative alignment of ICP4 gene showed that ICP4 A.A. identity percent of $100 \%$ homology, $98.9 \%$ to very virulent USA strain RB1B and MD70 and $100 \%$ for mild virulent and vaccinal strains.

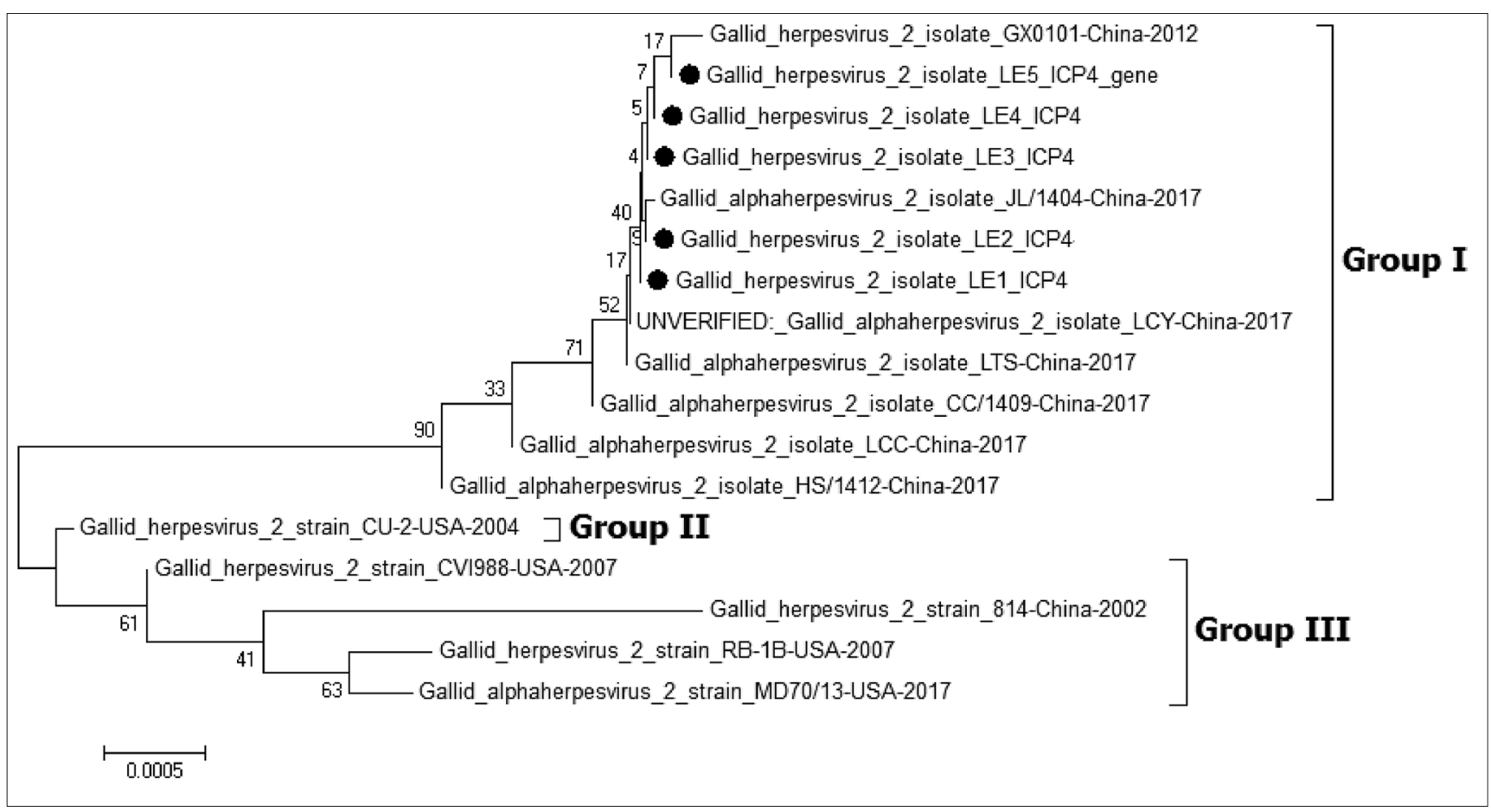

Figure-6: Phylogenetic tree of ICP4 gene of Marek disease virus (MDV). The figure shows the phylogenetic analysis of ICP4 gene of MDV gene reveling that all Egyptian strains cluster were related to very virulent European strains (YA, ATE, PC12/130). The MDV viruses in our study are indicated with a black dot.

and Chinese strains, mild virulent, vaccinal strains, and American strains) [37]. The Egyptian strains presented in this study were related to vv European strains, as previously described by Hassanin et al. [37]. They acquired new mutations divided into two subgroups A and $\mathrm{B}$. The strains in this study related to subgroup A possessed specific characteristic mutations.

The lengths of the $\mathrm{Meq}$ gene differ between vaccinal strains (CV1988, 814, and 3004), mild strains (CU-2), and virulent strains. In mild and vaccinal strains, Meq was $177 \mathrm{bp}$ longer than in virulent MDV strains (a 59-A.A. insertion), which inhibited the expression of the $M e q$ protein $[22,46]$. All strains in this study had short $M e q$ gene sequences, confirming the virulence of field
Table-2: The accession number of sequenced samples.

\begin{tabular}{clll}
\hline $\begin{array}{c}\text { No. Name of } \\
\text { sequenced } \\
\text { samples }\end{array}$ & $\begin{array}{l}\text { Accession } \\
\text { number } \\
\text { meq }\end{array}$ & $\begin{array}{l}\text { Accession } \\
\text { number } \\
\text { ICP4 }\end{array}$ & $\begin{array}{l}\text { Accession } \\
\text { number } \\
\text { GL }\end{array}$ \\
\hline
\end{tabular}

1. Gallid-herpesvirus- MT748026 MT748031 MT748036 2-isolate-LE1-ICP4

2. Gallid-herpesvirus- MT748027 MT748032 MT748037 2-isolate-LE2-ICP4

8. Gallid-herpesvirus- MT748028 MT748033 MT748038 2-isolate-LE3-ICP4

9. Gallid-herpesvirus- MT748029 MT748034 MT748039 2-isolate-LE4-ICP4

14. Gallid-herpesvirus- MT748030 MT748035 MT748040 2-isolate-LE5-ICP4

The table shows the accession number of Meq, ICP4, and $g L$ genes. 


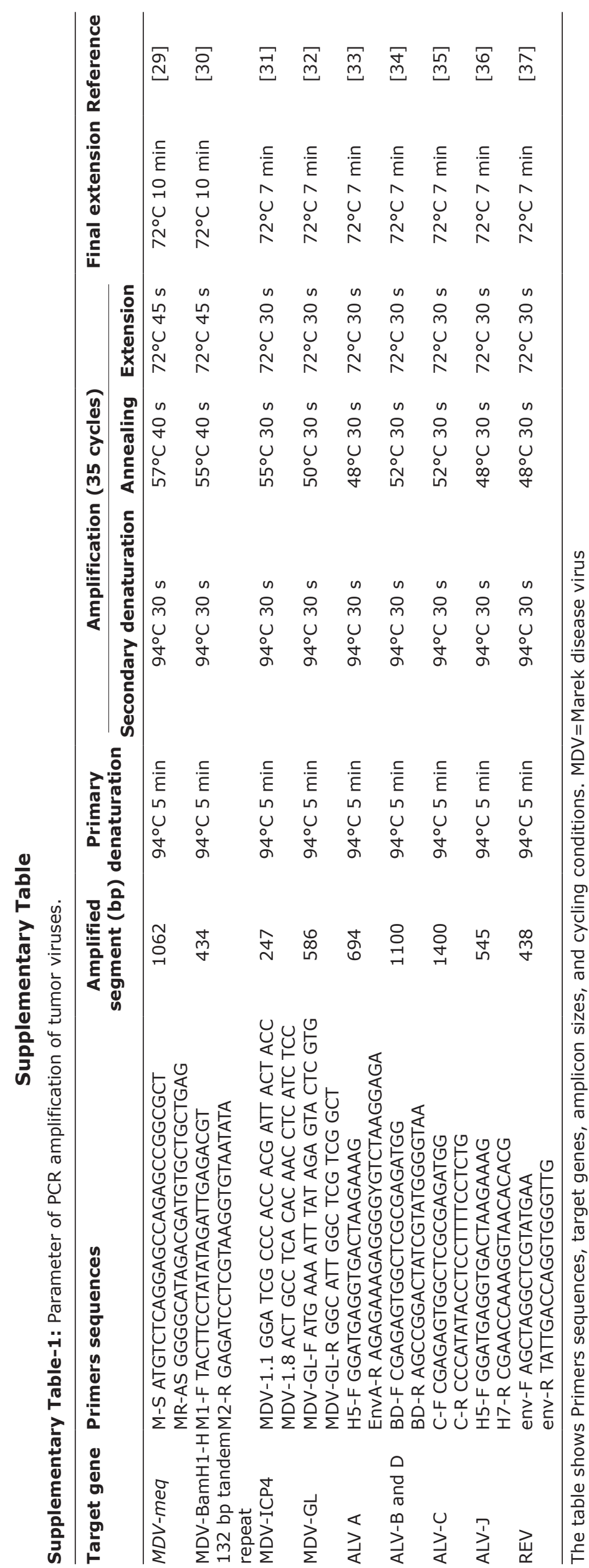


MDVs. Several A.A. point mutations were detected in the $M e q$ gene of Egyptian viruses in our study, similar to those identified in a previously isolated Egyptian strain, but with an additional new specific mutation at R176A that correlates with the virulence of MDV (as previously recorded for $\mathrm{vv}+\mathrm{MDVs}$ ) [13].

The A.A. identity of the five MDVs in this study showed low homology with CVI988 and $3004(82.5 \%)$. This low outcome is due to vaccination failure and outbreaks in Egypt despite intensive vaccination programs with the 3004 and CVI988 strains, as previously described by Lebdah et al. [28], Hassanin et al. [37], Zanaty et al. [43]. Further studies are, therefore, required to evaluate the efficacy of vaccines against vv strains, which breakout Egypt.

MDV $g L$ is important for entering viruses into host cells and transmission between cells [26]. Phylogenetic analysis of $g L$ in the current study divided strains into two groups (I and II). Group I contained vv European strains, Chinese strains, and mild virulent strains, and Group II comprised American strains [37]. The Egyptian strains were related to Group I, as previously recorded by Hassanin et al. [37]. The previous studies also detected a deletion in the $g L$ gene cleavage site in $\mathrm{vv}+$ strains isolated from the USA, hypothesized to perform an important role in increased virulence and pathogenicity of the virus [13]. In this study, the deletion was not detected in any virus.

The ICP 4 gene plays an important role in MDV replication $[47,48]$ and virus attenuation by acquiring multiple non-synonymous mutations during in vitro serial passages [49]. Phylogenetic analysis of the ICP4 gene also classified MDV into three groups (vv European and Chinese strains, mild and vaccinal strains, and American strains) as previously recorded [50]. Our MDV in this study clustered to the European/Chinese groups. A previous study reported HNGS101 isolated in China, contained multiple substitutions that altered the function of ICP4, decreasing the virulence and pathogenicity of the virus [51]. This study detected no virus mutations in ICP4 gene.

\section{Conclusion}

Twenty samples in our study were positive for MDV. The Egyptian strains in this study were related to the very virulent European viruses (Gallid herpesvirus $2 \mathrm{ATE}$ and $\mathrm{PC} 12 / 30$ ). They were clustered into new subgroups A and B by phylogenetic analysis distinct from the vaccine strains. Further studies should evaluate the protection contributed by current vaccines used in Egypt.

\section{Authors' Contributions}

HSE and SEO collected samples. NY, AE, and FA: Detection and molecular characterization of samples. All authors were involved in the writing, analysis of the data, and reviewed the manuscript. All authors read and approved the final manuscript.

\section{Acknowledgments}

The study was funded by the Animal Health Research Institute, Egypt.

\section{Competing Interests}

The authors declare that they have no competing interests.

\section{Publisher's Note}

Veterinary World remains neutral with regard to jurisdictional claims in published institutional affiliation.

\section{References}

1. Rozins, C., Day, T. and Greenhalgh, S. (2019) Managing Marek's disease in the egg industry. Epidemics, 27(10): 52-58.

2. Gimeno, I.M. and Schat, K.A. (2018) Virus-induced immunosuppression in chickens. Avian. Dis., 62(3): 272-285.

3. Calnek, B.W. and Witter, R.L. (1997) Marek's disease. In: Calnek, B.W., Barnes, H.J., Beard, C.W., McDougald, L.R. and Saif, Y.M., editors. Diseases of Poultry. $10^{\text {th }}$ ed. Iowa State University Press, Ames. p369-413.

4. OIE Terrestrial Manual. (2010) Marek's Disease OIE Manual for Diagnostic Techniques of Livestock Diseases. Office Internationals des Epizootics4, Paris, France. p496-506.

5. Payne, L. and Venugopal, K. (2000) Neoplastic disease: Marek's disease, avian leukosis and reticuloendotheliosis. Rev. Sci. Tech., 19(2): 544-564.

6. Davison, F. and Kaiser, P. (2004) Immunity to Marek's disease. In: Davison, F. and Nair, V., editors. Marek's Disease: An Evolving Problem. Elsevier Academic Press, London. p126-141.

7. Burrell, C.J., Howard, C.R. and Murphy, F.A. (2017) Pathogenesis of virus infections. In: Fenner and White's Medical Virology. Elsevier Public Health Emergency. p77-104.

8. ICTV International Committee on Taxonomy of Viruses. (2011) ICTV $9^{\text {th }}$ Report. Herpesviridae. Available from: https://www.talk.ictvonline.org/ictv-reports/ictv 9th report/dsdna-viruses-2011/w/dsdna_viruses/91/herpesviridae. Retrieved on 16-02-2018.

9. Dunn, J.R., Auten, K., Heidari, M. and Buscaglia, C. (2014) Correlation between Marek's disease virus pathotype and replication. Avian Dis., 58(2): 287-292.

10. OIE. (2016) Marek's Disease in OIE Terrestrial Manual, Paris. Available from: http://www.oie.int/fileadmin/Home/ eng/Healthstandards/tahm/2.03.13MAREK DIS.pdf. Retrieved on 12-08-2018.

11. Witter, R.L., Calnek, B.W., Buscaglia, C., Gimeno, I.M. and Schat, K.A. (2005) Classification of Marek's disease viruses according to pathotype: Philosophy and methodology. Avian Pathol., 34(2): 75-90.

12. Markowski-Grimsrud, C.J. and Schat, K.A. (2002)Cytotoxic T lymphocyte responses to Marek's disease herpesvirus-encoded glycoproteins. Vet. Immunol. Immunopathol., 90(34): $133-144$.

13. Shamblin, C.E., Greene, N., Arumugaswami, V., Dienglewicz, R.L. and Parcells, M.S. (2004) Comparative analysis of Marek's disease virus (MDV) glycoprotein-lytic antigen pp38 and transformation antigen Meq-encoding genes: Association of meq mutations with MDVs of high virulence. Vet. Microbiol., 102(3-4): 147-167.

14. Tian, M., Zhao, Y., Lin, Y., Zou, N., Liu, C., Liu, P., Cao, S., Wen, X. and Huang, Y. (2011) Comparative analysis of oncogenic genes revealed unique evolutionary features of field Marek's disease virus prevalent in recent years in China. Virol. J., 8(15): 121. 
15. Bertzbach, L.D., Laparidou, M., Härtle, S., Etches, R.J., Kaspers, B., Schusser, B. and Kaufer, B.B. (2018) Unraveling the role of B cells in the pathogenesis of an oncogenic avian herpesvirus. Proc. Natl. Acad. Sci. U. S. A., 115(45): 11603-11607.

16. Gimeno, I.M., Cortes, A.L., Reddy, S.M., de Juan, L., Abad, B., Käser, T. and Limsatanun, A. (2019) Highly virulent Marek's disease virus strains affect T lymphocyte function and viability of splenocytes in commercial meat type chickens. Avian Pathol., 48(6): 564-572.

17. Schat, K.A. and Nair, V. (2017) Neoplastic diseases. In: Swayne, D.E., editor. Diseases of Poultry. John Wiley and Sons, Inc., Hoboken, NJ, USA. p513-673.

18. Padhi, A. and Parcells, M.S. (2016) Positive selection drives rapid evolution of the meq oncogene of Marek's disease virus. PLoS One, 11(9): $\mathrm{e} 0162180$.

19. Alapanawe, S., Walkden-Brown, S.W., Renz, K.G. and Islam, A.F. (2016) Protection provided by rispens CVI988 vaccine against Marek's disease virus isolates of different pathotypes and early prediction of vaccine take and MD outcome. Avian Pathol., 45(1): 26-37.

20. Jarosinski, K.W., Tischer, B.K., Trapp, S. and Osterrieder, N. (2006) Marek's disease virus: Lytic replication, oncogenesis and control. Expert Rev. Vaccines, 5(6): 761-772.

21. McPherson, M.C. and Delany, M.E. (2016) Virus and host genomic, molecular, and cellular interactions during Marek's disease pathogenesis and oncogenesis. Poult. Sci., 95(2): 412-429.

22. Lee, S.I., Takagi, M., Ohashi, K., Sugimoto, C. and Onuma, M. (2000) Difference in the meq gene between oncogenic and attenuated strains of Marek's disease virus serotype1. J. Vet. Med., 62(3): 287-292.

23. Brown, A.C., Smith, L.P., Kgosana, L., Baigent, S.J., Nair, V. and Allday, M.J. (2009) Homodimerization of the meq viral oncoprotein is necessary for induction of T-cell lymphoma by Marek's disease virus. J. Virol., 83(21): 11142-11151.

24. Wozniakowski, G., Samorek-Salamonowicz, E. and Kozdrun, W. (2010) Sequence analysis of meq oncogene among Polish strains of Marek's disease. Pol. J. Vet. Sci., 13(2): 263-267.

25. Silva, R.F., Dunn, J.R., Cheng, H.H. and Niikura, M.A. (2010) MEQ-deleted Marek's disease virus cloned as a bacterial artificial chromosome is a highly efficacious vaccine. Avian Dis., 54(2): 862-869.

26. Wu, P., Reed W.M. and Lee, L.F. (2001) Glycoproteins $\mathrm{H}$ and $\mathrm{L}$ of Marek's disease virus form a hetero-oligomer essential for translocation and cell surface expression. Arch. Virol., 146(5): 983-992.

27. Awad, A.M. (2002) Studies on Marek's Disease in Commercial Broiler Chickens. Ph.D.Thesis. Alexandria University, Alexandria, Egypt.

28. Lebdah, M.A., Nassif, A., Shahein, S.M. and El-Basrey, Y. (2017) Isolation and identification of very virulent strains of Marek's disease virus from MDV-vaccinated flocks in Egypt. Zagazig Vet. J., 45(3): 197-192.

29. Mitra, N., Verma, R. and Singh, A. (2013) Molecular and pathological analysis of oncogenic virus induced multiple infections in chickens reared under Indian conditions. Natl. Acad. Sci. Lett., 36(3): 271-277.

30. Fenton, S.P., Reddy, M.R. and Bagust, T.J. (2005) Single and concurrent avian leukosis virus infections with avian leukosis virus-J and avian leukosis virus-A in Australian meat-type chickens. Avian Pathol., 34(1): 48-54.

31. Dorner, A.J. and Coffin, J.M. (1986) Determinants for receptor interaction and cell killing on the avian retrovirus glycoprotein gp85. Cell, 45(3): 365-374.

32. Silva, R.F., Fadly, A.M. and Taylor, S.P. (2007) Development of a polymerase chain reaction to differentiate avian leukosis virus (ALV) subgroups: Detection of an ALV contaminant in commercial Marek's disease vaccines. Avian Dis., 51(3): 663-667.

33. Smith, L.M., Brown, S.R., Howes, K., McLeod, S.,
Arshad, S.S., Barron, G., Venugopal, G., McKay, J.C. and Payne, L.N. (1998) Development and application of polymerase chain reaction (PCR) tests for the detection of subgroup J avian leukosis virus. Virus Res., 54(1): 87-98.

34. Wei, K., Sun, Z., Zhu, S., Guo, W., Sheng, P., Wang, Z., Zhao, C., Zhao, Q. and Zhu, R. (2012) Probable congenital transmission of reticuloendotheliosis virus caused by vaccination with contaminated vaccines. PLoS One, 7(8): e43422.

35. Murata, S., Chang, K.S., Lee, S.I., Konnai, S., Onuma, M. and Ohashi, K. (2007) Development of a nested polymerase chain reaction method to detect oncogenic Marek's disease virus from feather tips. J. Vet. Diagn. Invest., 19(5): 471-478.

36. Handberg, K.J., Nielson, O.L. and Jorgensen, P.H. (2001) Use of serotype 1 and serotype 3 specific polymerase chain reaction for the detection of Marek's disease virus in chickens. Avian Pathol., 30(3): 243-249.

37. Hassanin, O., Abdallah, F. and El-Araby, I.E. (2013) Molecular characterization and phylogenetic analysis of Marek's disease virus from clinical cases of Marek's disease in Egypt. Avian Dis., 57(2s1): 555-561.

38. Gong, Z., Zhang, L., Wang, J., Chen, L., Shan, H., Wang, Z. and Ma, H. (2013) Isolation and analysis of a very virulent Marek's disease virus strain in China. Virol. J., 10: 155.

39. Abd-Ellatieff Hoda, A., Abdelrahman, A., Rawash, A., Hany, F.E., Wael, M.G. and Tokuma, Y. (2017) Molecular characterization and phylogenetic analysis of a virulent Marek's disease virus field strain in broiler chickens in Japan. Avian Pathol., 47(1): 47-57.

40. Bertzbach, L.D., Kheimar, A., Ali, F.A.Z. and Kaufer, B.B. (2018) Viral factors involved in Marek's disease virus (MDV) pathogenesis. Curr. Clin. Microbiol. Rep., 5(12): 238-244.

41. Kheimar, A., Previdelli, R.L., Wight, D.J. and Kaufer, B.B. (2017) Telomeres and telomerase: Role in Marek's disease virus pathogenesis, integration and tumorigenesis. Viruses, 9(7): 173.

42. Kheimar, A., Trimpert, J., Groenke, N. and Kaufer, B.B. (2018) Overexpression of cellular telomerase RNA enhances virus-induced cancer formation. Oncogene, 38(10): 1778-1786.

43. Zanaty, A., Mady, W., Soliman, M., Samy, M., Erfan, A., Arafa, A. and Hassan, M. (2017) Genetic and pathological characterization of Marek's disease virus in Egypt. Anim. Health Res. J., 5(1): 201-209.

44. Ajithdoss, D.K., Reddy, S.M., Suchodolski, P.F., Lee, L.F., Kung, H.J. and Lupiani, B. (2009) In vitro characterization of the Meq proteins of Marek's disease virus vaccine strain CVI988. Virus Res., 142(1-2): 57-67.

45. Levy, A.M., Izumiya, Y., Brunovskis, P., Xia, L., Parcells, M.S., Reddy, S.M., Lee, L., Chen, H., Kung, H. and Irol, J.V. (2003) Characterization of the chromosomal binding sites and dimerization partners of the viral oncoprotein Meq in Marek's disease. J. Virol., 77(23): 12841-12851.

46. Chang, K.S., Ohashi, K. and Onuma, M. (2002) Diversity (polymorphism) of the Meq gene in the attenuated Marek's disease virus (MDV) serotype 1 and MDV-transformed cell lines. J. Vet. Med. Sci., 64(12): 1097-1101.

47. Pratt, W.D., Cantello, J., Morgan, R.W. and Schat, K.A. (1994) Enhanced expression of the Marek's disease virus-specific phosphoproteins after stable transfection of MSB-1 cells with the Marek's disease virus homolog of ICP4. Virology, 201(1): 132-136.

48. Kato, K., Izumiya, Y., Tohya, Y., Takahashi, E., Hirai, K. and Kawaguchi, Y. (2002) Identification and characterization of Marek's disease virus serotype 1 (MDV1) ICP22 gene product: MDV1 ICP22 transactivates the MDV1 ICP27 promoter synergistically with MDV1 ICP4. Vet. Microbiol., 85(4): 305-313.

49. Hildebrandt, E., Dunn, J.R., Perumbakkam, S., Niikura, M. and Cheng, H.H. (2014) Characterizing the molecular basis 
of attenuation of Marek's disease virus via in vitro serial passage identifies de novo mutations in the helicase-primase subunit gene UL5 and other candidates associated with reduced virulence. J. Virol., 88(11): 6232-6242.

50. He, L., Li, J., Zhang, Y., Luo, J., Cao, Y. and Xue, C. (2018)

Phylogenetic and molecular epidemiological studies reveal evidence of recombination among Marek's disease viruses. Virology, 516(3): 202-209.

51. Lv, H., Zhang, Y., Sun, G., Bao, K., Gao, Y., Qi, X., Cui, H., Wang, Y., Li, K., Gao, L., Pan, Q., Wang, X. and Liu, C. (2017) Genetic evolution of Gallidherpesvirus 2 isolated in China. Infect. Genet. Evol., 51(7): 263-274.

$* * * * * * * *$ 